\title{
Geographical Indication as a Tool for Regional Development: An Opportunity for Small Farmers to Excel in the Market
}

\author{
Alan Malacarne, Liaria Nunes-Silva, and Robelius De-Bortoli
}

\begin{abstract}
Agribusinesses engage in a form of production in which only the big producer benefits while family farming suffers from a scarcity of opportunities. Given this scenario, how can the family farmer successfully contribute to national agricultural production and not have to depend solely on subsistence farming? The objective of this study is to analyze the food production network in Brazil within each of its five geographic regions. This work is classified as applied research, as its purpose is to generate knowledge and practical applications in order to solve problems. In order to support this aim, this paper includes a bibliographical survey of the bases of public domain with documentary searches conducted at the Brazilian Institute of Geography and Statistics (IBGE). The results show that the data on food production in the five large Brazilian regions differs significantly and shows how the agrobusiness model, where only large landowners generate wealth, is harmful to small producers. Thus, it is concluded that one of the solutions for these small producers is to innovate and thereby give their products added value. The use of Geographical Indications would help to support these small producers in their efforts to thrive.
\end{abstract}

Index Terms - Geographical indication, regional development, agribusiness, family agriculture.

\section{INTRODUCTION}

Although family farming is considered by many institutions as being part of agribusiness, it is not so in practice [1]. The production of family farms is threatened by many factors such as the lack of wealth, power, capital and technology. There exists the argument that the interests of large agribusinesses largely dominate the markets and are instigating the weakening of family agriculture. However, strengthening smallholder organizations can increase their political power and this, coupled with increased support from civil society, has the potential to change the direction of the current Brazilian rural development model and increase the share of family agriculture in the gross value of national production. Smallholder farmers face some challenges in their attempts to succeed in agribusiness, such as weak educational systems, limited access to the internet, and competition from large farms with the technology to increase productivity [2]. One way to improve the situation of small and medium-sized farmers is to innovate and develop their businesses.

Manuscript received February 12, 2019; revised April 12, 2019.

Alan Malacarne, Liara Nunes-Silva, and Robelius De-Bortoli is with the Graduate Program in Intellectual Property of the Federal University of Sergipe, Brazil (e-mail: alanmalacarne1988@gmail.com, liaria.nunes@ifpi.edu.br, robelius@yahoo.com.br).
One way to improve the situation of small and medium-sized farmers is to innovate and develop their businesses. It is widely believed that entrepreneurship is beneficial to economic growth and its development has been incredibly resurgent over the past three decades in countries that have achieved a substantial reduction in poverty. Indeed, an increase of $1 \%$ in business activities reduces the poverty rate by $2 \%$.

Studies show that entrepreneurship is a means of identifying value-added activities that increase efficiency and employment opportunities [2]. Entrepreneurs with successful companies are employees who manage their own businesses. In this way, the rural worker becomes an innovative agent of change who finds opportunities to use the land and its resources for specialized, value-based, and agriculture-based enterprises. This combination of agriculture and business is generally conceptualized as Agro-entrepreneurship [3].

Agribusiness today engages in a form of production where only the big producer is benefited, while family farming is suffering from a scarcity of opportunities. Given this scenario, what is the best way out for the family farmer to also contribute successfully to the nation's production and not depend solely on subsistence agriculture? The objective of this study is to analyze the food production network in Brazil across its geographic regions.

\section{Methodology}

\section{A. Research Process}

This paper is classified as applied research, as its objective is to generate knowledge and offer practical applications in order to solve problems [4]. In terms of to its objectives, the research is characterized as descriptive, since it establishes relationships between variables and facts [5]. The approach to the problem is a qualitative / quantitative, since it uses statistical resources and techniques as well as an interpretative approach to data reality [6].

\section{B. Data Collection}

A bibliographical survey was carried out at the public domain databases with documentary searches of the Brazilian Institute of Geography and Statistics (IBGE). The "cities" database was accessed with recent data on the organization of agribusinesses and grain and legume production in Brazil, divided by geographic regions. The results are presented in a descriptive way, comparing the production, populations and extensions of the agrarian territories. 


\section{Procedures (How the Data Collection was Performed at the IBGE)}

First, data on the population size of the urban and rural areas of the Brazilian regions was collected and grouped in the year 2015. Data on the Brazilian production of grains and legumes was also collected, but only the data on the food products produced in all of the national regions. Soon after, the data pertaining to the quantity of properties and their size was collected, these being in familiar agriculture and also in relation to the individual producers.

\section{RESULTS}

The following is the data about the Brazilian regions and their population structure. Fig. 1 presents the percentage values of rural populations in the different regions of Brazil. Comparing the regions, it displaces the Southeast Region with $7.37 \%$ and the North and Northeast regions with a percentage higher than $33 \%$.

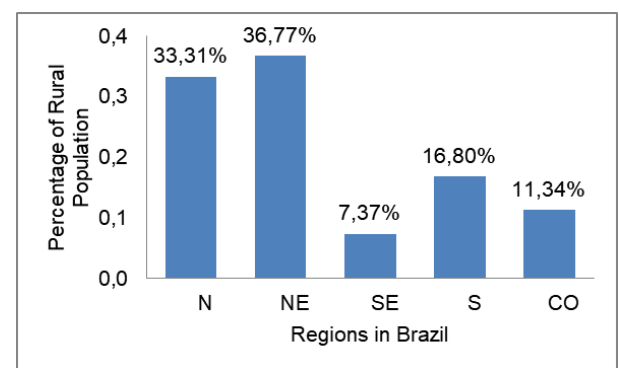

Fig. 1. Percentage of rural population in large Brazilian regions.

Table I presents data on the Brazilian production of grains and legumes per inhabitant in the year 2018 per major region of the country. Note that the Southeast Region has the lowest ratio between production and inhabitant. This is associated with the fact that the North and Northeast also have low production numbers per inhabitant.

TABLE I: BRAZILIAN FOOD PRODUCTION PER CAPITA, ACCORDING TO EACH

\begin{tabular}{|c|c|c|c|c|c|}
\hline \multicolumn{6}{|c|}{ MAJOR REGION } \\
\hline Production/inhabitant & $\mathrm{N}$ & $\mathrm{NE}$ & $\mathrm{SE}$ & $\mathrm{S}$ & $\mathrm{CO}$ \\
\hline $\begin{array}{l}\text { Peanut in shell (1st } \\
\text { harvest) }\end{array}$ & 0,04 & 0,04 & 1,53 & 0,15 & 0,07 \\
\hline Rice (in shell) & 13,65 & 4,52 & 0,18 & 42,63 & 13,00 \\
\hline $\begin{array}{l}\text { Beans (in grain) 1st } \\
\text { harvest }\end{array}$ & 2,39 & 19,73 & 2,68 & 9,84 & 5,43 \\
\hline $\begin{array}{l}\text { Beans (in grain) 2nd } \\
\text { harvest }\end{array}$ & 2,58 & 8,26 & 1,69 & 8,29 & 16,27 \\
\hline $\begin{array}{l}\text { Beans (in grain) 3rd } \\
\text { harvest }\end{array}$ & 0,01 & 0,00 & 1,15 & 0,17 & 6,26 \\
\hline $\begin{array}{l}\text { Corn (in grain) 1st } \\
\text { harvest }\end{array}$ & 21,27 & 34,39 & 14,54 & 47,54 & 20,62 \\
\hline $\begin{array}{l}\text { Corn (in grain) 2nd } \\
\text { harvest }\end{array}$ & 15,60 & 12,58 & 9,40 & 73,39 & 475,01 \\
\hline Soy (in grain) & 100,92 & 53,56 & 27,85 & 407,18 & 996,85 \\
\hline
\end{tabular}

Table II shows the Brazilian production of legumes and grains per inhabitant of the rural area in the year 2018. The data shows that, when analyzed, the relative values of production by inhabitants of the rural environment of grain production show that the North and Northeast Regions are the smallest producers, and yet the Southeast region is no longer the region with the lowest values.
TABLE II: BRAZILIAN FOOD PRODUCTION PER INHABITANT OF THE RURAL AREA, ACCORDING TO EACH MAJOR REGION

\begin{tabular}{|c|c|c|c|c|c|}
\hline Production/Rural & $\mathrm{N}$ & $\mathrm{NE}$ & SE & $\mathrm{S}$ & $\mathrm{CW}$ \\
\hline $\begin{array}{l}\text { Peanut in shell (1st } \\
\text { harvest) }\end{array}$ & 0,17 & 0,15 & 22,33 & 1,04 & 0,67 \\
\hline Rice (in shell) & 54,61 & 16,80 & 2,62 & 296,29 & 127,64 \\
\hline $\begin{array}{l}\text { Beans (in grain) 1st } \\
\text { harvest }\end{array}$ & 9,57 & 73,39 & 39,04 & 68,42 & 53,27 \\
\hline $\begin{array}{l}\text { Beans (in grain) 2nd } \\
\text { harvest }\end{array}$ & 10,31 & 30,72 & 24,57 & 57,62 & 159,71 \\
\hline $\begin{array}{l}\text { Beans (in grain) 3rd } \\
\text { harvest }\end{array}$ & 0,05 & 0,00 & 16,78 & 1,17 & 61,49 \\
\hline $\begin{array}{l}\text { Corn (in grain) 1st } \\
\text { harvest }\end{array}$ & 85,12 & 127,94 & 211,88 & 330,44 & 202,43 \\
\hline $\begin{array}{l}\text { Corn (in grain) 2nd } \\
\text { harvest }\end{array}$ & 62,43 & 46,78 & 136,91 & 510,12 & 4662,54 \\
\hline Soy (in grain) & 403,85 & 199,24 & 405,75 & 2830,16 & 9784,65 \\
\hline
\end{tabular}

In the two previous cases in both Table I and Table II, the Central-West region presents high values in production compared to the other regions of Brazil. Fig. 2 shows the average percentage of areas of Brazil's rural properties according to each major region of the country

This graph shows the average size of areas for family farming. The regions which present distinct profiles of higher and lower grain yields (Midwest and North) have average areas larger than those of the other regions. It is worth mentioning that the Northeast Region, with characteristics of low production per inhabitant, has an smaller average area of properties than the other regions.

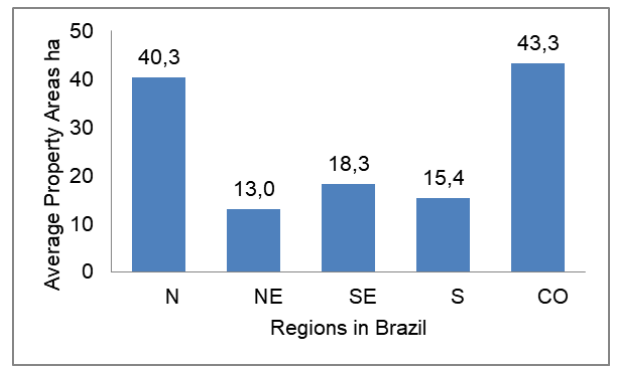

Fig. 2. Percentage of the average area of rural properties per hectare in large Brazilian regions. Data source: IBGE, 2006.

Fig. 3 shows the data of the average area of individual production per hectare of the greater Brazilian regions. It can be observed that, as in Fig. 2, the data of Figure 3 reinforces the fact that both the Central-West and Northern regions have higher area values, and again the Northeast region has lower values than the other regions in terms of individual agricultural production.

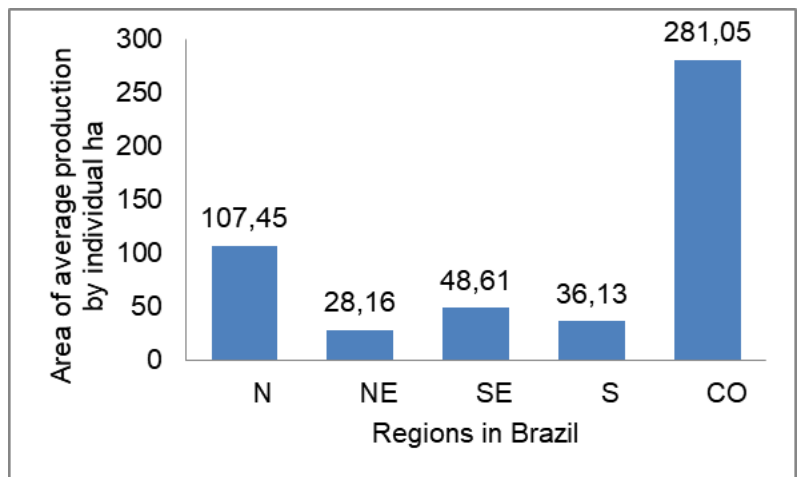

Fig. 3. Percentage of the average area of individual agricultural production in large Brazilian regions. Data source: IBGE , 2006. 


\section{DISCUSSION}

The sovereignty of national food production is dependent on family agriculture. Since this segment of agriculture is essential for rural and regional development, these same farmers should be able to supply the food needs of its region in quantity and quality. However, the industrialization of agricultural production has transformed rural spaces into large latifundia, where only the great owners succeed because the small producers have lost their spaces in the plantations where the production is mechanized in all of its stages. What remains for these rural men is to migrate to large urban centers in search of a better life, thus increasing the so-called rural exodus. Rural and regional development goes far beyond the vision of capital and profit for the large latifundia, as it involves historical, environmental and social issues [7]-[10].

The standard model of modern agriculture is being replaced by rural development in search of a new model for agriculture, with a focus on fostering cohesion with local ecosystems [11]. It is necessary to have an agricultural system that considers sustainable development, natural preservation, social inclusion, and reduction of inequalities [12]-[14]. One way for this new form of conducting agriculture is through innovation and entrepreneurship [2]. Small farmers need to rethink how to manage their land and move from subsistence agriculture to an agriculture that makes it possible to evolve in all sectors of business and life. In this context, Geographical Indication (GI) is very useful for small farmers, because it is a record that has a link between the place where a product is made and the quality of that product, generating a differentiated product with the capacity to attract consumers and stand out in the market [15], [16].

Differences in agrarian development in large Brazilian regions

Although the largest productive area in the country, the Central-West region, has a much higher productive potential (for the quality of its soil) than the one we see today with its planted crops [17]. Something else that makes the Center-West region stand out from other Brazilian regions is the topography of their lands - they are flat, which facilitates the use of the most varied types of mechanization [18]. The Central-West region as well as the Northern region had in an extensive way the expansion of agricultural production, changing the family agriculture businesses into the modern and mechanized agriculture of the latifundia. This resulted in greater agricultural productivity in comparison with the other regions of the country as we can see in Tables I and II, but there was also a reduction in the number of workers in agriculture in these regions [19]. The industrialization of crops in the region increased the country's production indicators, but also had serious consequences for small producers and the entire region, bringing negative environmental impacts and increasing the population problem in the big cities due to the increase in rural exodus.

Due to the fact that it is covered by the Amazon forest for almost all of its entirety, the Northern region of Brazil, despite having $45 \%$ of all of the geographic area of the country, contributes a mere $5 \%$ of the Gross Domestic Product (GDP) and only $8 \%$ of population. An enormous governmental effort has been made to control the harmful environmental impacts that are occurring in this region because of the unbridled advance of industrialized agriculture [20], [21]. In the Amazon forest other Brazilian biomes, such as the Cerrado and Caatinga, have been losing their natural vegetation over the years [22]. Despite the uncontrolled growth of industrial agriculture in recent years in the North, if we look at Figure 3, we can see that the Central-West region, which has the average area of properties similar to that of the North as shown in Fig. 2, has an individual production quota greater than this region.

The Northeast region was one of the first to be occupied in Brazil, but besides being a region plagued by an arid climate, it has very low social and economic development indexes when compared to the other regions of the country. With less than $14 \%$ of GDP, the Northeast has an extensive territory that makes up $18 \%$ of the national area [23]. The illiteracy rate is high and the northeastern region has a per capita income of less than half the national average. In recent decades, agriculture in the Northeast region, which had previously been labor intensive with crops such as sugarcane plantations, has been losing more and more space for industrialized agriculture, reducing the possibility of employment for rural workers [21]. Thus, despite having 50\% of the country's agricultural employment, small farmers in this region must work to survive, that is, they live on subsistence agriculture. All of this shows why this region has the lowest rate of individual production in Brazil, as we can see in Fig. 3 [19]. And even though it has a large index of workers in rural areas as shown in Fig. 1, these workers do not see a financial and social return, because their production rates are low as shown in Tables I and II.

The region with the highest industrialization index in agriculture and in other sectors is the Southeast region, this region as well as the Southern region have a tendency to reduce employment in the agricultural sector [24]. As we can see in Fig. 2, the average size of the areas for family agriculture in these two regions is much smaller when compared to the North and Central West regions, so their indicators are below the national average. Crops such as sugar cane, coffee and oranges, that used to use a lot of manpower, today use a modern mechanized system which has been increasingly decreasing agricultural employment. Also linked to this region is one that has the least amount of farmers in family farming [19]. Agricultural production per capita is low in the Southeast, suggesting that the rural area would be responsible for production. If this proposition were true, the North and Northeast Regions, which have more inhabitants in the rural areas, would be larger grain producers, yet the data does not illustrate this theory.

The state of family agriculture and regional development thrives in the southern region of Brazil, even though it is not among the largest producing regions of Brazil in the sense of large-scale latifundia agriculture, as is the case in the Central-West region [25]. In the South, the infrastructures of the properties as well as the good levels of production and income are the differentials. Thus, it can be noted that the South region is a role model in presenting innovative and entrepreneurial activities that give results. It is also one of the regions with the most registered GIs, having 16 regions covered by the protection of Intellectual Property. 


\section{CONCLUSIONS}

Number As we can see, the agribusiness industry is directed at helping the big producers, leaving the small producer at a disadvantage. The data about the five great Brazilian regions show that this is indeed a fact. Whereas the greater industrialization of the crops leads to more financial profit, it also leads to the misery of small producers, who live on subsistence agriculture. One viable solution for these small farmers is to invest in innovation, giving added value to their products, and protecting them with GIs. GIs go hand-in-hand with family farming, as they encompass a whole region where small producers work together to produce a differentiated, quality product and have a good financial return, if well managed. With this logic, GIs are certainly one of the possible paths towards rural entrepreneurship, and, like in Southern region, demonstrate that the indicators of production do not always show the true success of agribusiness, since this goes beyond the large scale productions that only benefit a small part of society. The true value is linked to the conservation of the environment through sustainable practices, and social and economic development for the entire rural population.

\section{ACKNOWLEDGEMENTS}

This work would not have been possible without the support of the Postgraduate Program in Intellectual Property of the Federal University of Sergipe and the Foundation for Research and Technological Innovation Support of the State of Sergipe (Fapitec/SE). Special thanks to the LADEC team.

\section{REFERENCES}

[1] B. M. Fernandes, "Questão agrária e capitalismo agrário: O debate paradigmático de modelos de desenvolvimento para o campo," Reforma Agrária, vol. 35, no. 2, pp. 41-53, 2014.

[2] R. Potrich and D. Grzybovski, "Transformações contemporâneas do trabalho em pequenas propriedades rurais: Uma reflexão crítica com base nas capacidades empreendedoras e inovativas do agricultor familiar," Revista Brasileira de Estudos Organizacionais, vol. 4, no. 1, pp. 220-251, 2017.

[3] S. L. Bairwa, K. Lakra, S. Kushwaha, L. K. Meena, and P. Kumar, "Agripreneurship development as a tool to upliftment of agriculture," International Journal of Scientific and Research Publications, vol 4, no. 3, pp. 1-4, 2014.

[4] E. L. D. Silva and E. M. Menezes, Metodologia Da Pesquisa E Elaboração de Dissertação, Florianópolis: UFSC, 2005.

[5] A. L. Cervo, P. A. Bervian, and R. D. Silva, Metodologia cientíFica, São Paulo: Ed. Prentice Hall, 2007, ch 2.

[6] M. D. A. Marconi and E. M. Lakatos, Fundamentos de Metodologia científica, São Paulo: Atlas, 2003.

[7] J. C. Tedesco, Terra, Trabalho e Família: Racionalidade Produtiva e Ethos Camponês, Passo Fundo: EDIUPF, 1999.

[8] M. D. N. B. Wanderley, "A emergência de uma nova ruralidade nas sociedades modernas avançadas - o "rural" como espaço singular e ator coletivo," Estudos Sociedade e Agricultura, vol. 15, no. 87, pp. $87-145,2000$.

[9] K. D. C. S. Nunes and L. B. Neto, "Urbano e rural: Contradições e influências no (re) pensar da ruralidade no Brasil," Revista Exitus, vol. 6, no. 1, pp. 62-76, 2016.

[10] N. L. S. D. Silva, L. C. Lunardi, P. C. S. D. Silva, W. J. Zonin, V. H. Pereira, K. L. Rocha, and G. Martins, "O jovem rural e as perspectivas da sucessão nas propriedades de agricultura familiar,’ Paraná: Unioste, 2017, pp. 36-53.

[11] J. D. V. D. Ploeg, H. Renting, G. Brunori, K. Knickel, J. Mannion, T. Marsden, and F. Ventura, "Rural development: From practices and policies towards theory," Sociologia Ruralis, vol. 40, no. 4, pp. 391-408, 2000.

[12] H. Wang, F. Qiu, and B. Swallow, "Can community gardens and farmers' markets relieve food desert problems? A study of edmonton, Canada," Applied Geography, vol. 55, pp. 127-137, 2014.
[13] J. B. M. Neto, "Reflexões sobre os espaços rurais: Caminhos para o desenvolvimento rural brasileiro," Revista Rural \& Urbano, vol. 2, no. 2, pp. 2-25 2017.

[14] L. V. Camus and C. Kay, "The agrarian political economy of left-wing governments in Latin America: Agribusiness, peasants, and the limits of neo-developmentalism," Journal of Agrarian Change, vol. 17, no. 2, pp. 415-437, 2017.

[15] T. Josling, "The war on terroir: Geographical indications as a transatlantic trade conflict," Journal of Agricultural Economics, vol. 57, no. 3, pp. 337-363, 2006

[16] G. Moschini, L. Menapace, and D. Pick, "Geographical indications and the competitive provision of quality in agricultural markets," American Journal of Agricultural Economics, vol. 90, no. 3, pp. 794-812, 2008.

[17] C. V. Manzatto, A. R. Filho, T. Costa, M. Santos, M. R. Coelho, E. D. Silva, and R. D. Oliveira, Potencial de Uso e Uso Atual Das Terras. Uso Agrícola Dos Solos Brasileiros, Rio de Janeiro: Embrapa Solos; 2002.

[18] R. E. Freitas, M. A. A. D. Mendonça, and G. D. O. Lopes, "Expansão de área agrícola nas mesorregiões brasileiras," Revista de Política Agrícola, vol. 20, no. 1, pp. 100-116, 2011

[19] L. Mattei, Emprego agríCola: Cenários E tendêNcias, Estudos Avançados, vol. 29, no. 85, pp. 35-52, 2015.

[20] F. Gollnow and T. Lakes, "Policy change, land use, and agriculture: The case of soy production and cattle ranching in Brazil," Applied Geography, vol. 55, pp. 203-211, 2014.

[21] C. C. Diniz, "Dinâmica regional e ordenamento do território brasileiro: desafios e oportunidades," Revista Catarinense de Economia, vol. 1, no. 1, pp. 1-27, 2017.

[22] R. Beuchle, R. C. Grecchi, Y. E. Shimabukuro, R. Seliger, H. D. Eva, E. Sano, and F. Achard, "Land cover changes in the Brazilian Cerrado and Caatinga biomes from 1990 to 2010 based on a systematic remote sensing sampling approach," Applied Geography, vol. 58, pp. 116-127, 2015.

[23] E. V. Araújo, B. A. M. D. Socorro, and Y. S. Sampaio, "Impactos ambientais da agricultura no processo de desertificação no Nordeste do Brasil," Revista de Geografia, vol. 22, no. 1, pp. 90-112, 2005.

[24] C. P. B. Rodrigues and J. M. D. Santos, "A evolução da qualidade do emprego na agropecuária brasileira: Uma avaliação do período 1990-2010," Revista de Economia e Agronegócio, vol. 11, no. 3, pp. 304-323, 2015.

[25] T. J. A. D. Oliveira, S. H. Dorner, and P. F. A. Shikida, "A agricultura familiar e o desenvolvimento rural no nordeste do Brasil: Uma análise comparativa com a região sul," Acta Tecnológica, vol. 10, no. 2, pp. 59-74, 2017

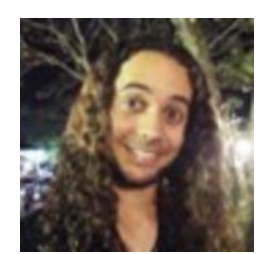

Alan Malacarne was born in Espírito Santo, Brazil. $\mathrm{He}$ has a $\mathrm{PhD}$ in intellectual property science at the Federal University of Sergipe. He is a professor of physical education, a specialist in sports training and a master in intellectual property science.

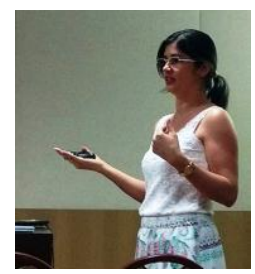

Liaria Nunes-Silva was born in Piauí, Brazil. She has a $\mathrm{PhD}$ in intellectual property science at the Federal University of Sergipe. She holds a bachelor of business administration - FCP and a master in science of intellectual property - UFS. She is a professor of administration at the Federal Institute of Plauí.

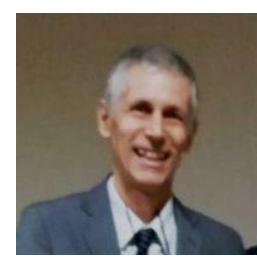

Robelius De-Bortoli was born in Rio Grande do Sul, Brazil. He has a degree in physical education, specialist in football administration and marketing - UGF.

He received her doctor of physical activity science in Unileon and the post-doctorate from the University of Costa Rica. He teaches physical education and the postgraduate program in intellectual property sciences at the Federal University of Sergipe. 